\title{
The Role of Net Working Capital in the Financing of the Operating Activities of Mining Companies
}

\author{
Maria SIERPIŃSKA, Małgorzata KOWALIK
}

\author{
1) Uniwersytet Ekonomiczny w Krakowie \\ http://doi.org/10.29227/IM-2021-01-16 \\ Submission date: 19-01-2021 | Review date: 04-05-2021
}

\begin{abstract}
The paper examines how companies' net working capital is used to finance their operating activities. Net working capital is a source of long-term financing (equity and long-term external capital) and is more expensive than financing through short-term sources, hence its rational use has a significant impact on the efficiency of companies' operations. The computed level of net working capital is used to calculate ratios enabling companies to control this capital. The ratios indicate the relationship of net working capital to current assets, to the sum of accounts receivable and short-term investments, to cash and cash equivalents, and sales revenues. Based on these calculations of the relationships, an assessment was made of net working capital engagement in the financing of operating activities in mining companies. These companies maintain a high degree of current asset financing through long-term capital. In mining companies with diverse mining activities, the level of current assets financing through long-term capital is higher than in coal mining companies. This is due to the maintenance of a higher level of inventories of extracted raw materials, the distance of outlets from the place of extraction and the method of transport used. Based on the ratio of net working capital to cash and cash equivalents, it was found that some companies were overly liquid. Cash balances significantly exceed the value of this capital over a period of three to four years. A surplus of cash over net working capital in the short term cannot be treated as excess liquidity, as it is the due to flexible management of this capital.
\end{abstract}

Keywords: net working capital, net working capital ratios, excess liquidity

\section{Introduction}

The dynamic environment in which companies operate and changes in the economic situation make the management of net working capital increasingly important. In the company's financing structure, net working capital is like the circulatory system in the human body. When managed effectively, it allows the company to remain financially healthy and competitive. When it is not afforded the attention it deserves, it leads to payment gridlocks and sometimes to bankruptcy (Skoczylas, 2015). Early identification of problems requires the company to have tools with which it can control changes in the level of net working capital relative to current needs. To determine whether the level of net working capital is rational, the ratio of this capital to total assets, current assets, total accounts receivables and short-term investments, cash and cash equivalents, and sales revenues is calculated. Besides accounts payable, net working capital is a source of financing of current assets. When its level is too low in relation to the needs, this leads to a loss of liquidity and an increase in cost of goods sold (COGS) in the form of penalty interest. An excessive level of working capital increases opportunity costs and the average cost of capital. This prompts companies to systematically monitor its level and rationally manage this capital.

The paper aims to present the results of research into the share of net working capital in the financing of operating activities in Polish and global mining companies. An attempt was made to verify the hypothesis predicting that Polish coal companies manage their net working capital more rationally than global companies. They do not keep an excessive level of working capital and do not generate opportunity costs.
The net working capital (NWC) affords the company a safety buffer that reduces the liquidity risk. It is more expensive than short-term capital, hence its size has an impact on the efficiency of the company's operations. Relevant literature presents two ways in which NWC is calculated - capital related, and assets related. Under the capital related approach, net working capital is the difference between the values of capital and long-term debt and non-current assets. Under the assets related approach, it is calculated as the difference between current assets and short-term liabilities. The formulas presented above indicate that the calculation of NWC requires the transformation of the accounting balance into an itemised balance. Capital and long-term debt consists of all sources of assets financing with a period of return in excess of the balance sheet year. Short-term liabilities include short-term provisions, accounts payable and short-term accruals with a maturity of up to one year. Non-current assets are the sum of fixed assets and trade receivables with a return period over 12 months. Current assets are those that can be converted into cash within less than the balance sheet year.

Net working capital may be positive, which means that the company finances all its fixed assets and a part of its current assets through capital and long-term debt. Negative net working capital values indicate a lack of full coverage of even fixed assets through non-current sources of financing. All current assets and part of the fixed assets are then financed through short-term financing sources. Lack of net working capital means that current assets are financed through shortterm sources and fixed assets through long-term financing sources. Positive net working capital is well received by the company's environment as it indicates that there is no risk of loss of liquidity (Szemraj, Czajkowska, 2020). It should be 
Tab. 1. Share of net working capital in mining companies' current assets, 2015-2019. Source: own calculations based on financial statements of mining companies retrieved from a Reuters database

Tab. 1. Udział kapitału obrotowego netto w aktywach obrotowych w spółkach górniczych w latach 2015-2019. Źródło: obliczenia własne na podstawie sprawozdań finansowych spółek górniczych zaczerpnięte z bazy Reuters

\begin{tabular}{|l|r|r|r|r|r|}
\hline Company & $\mathbf{2 0 1 5}$ & $\mathbf{2 0 1 6}$ & $\mathbf{2 0 1 7}$ & $\mathbf{2 0 1 8}$ & $\mathbf{2 0 1 9}$ \\
\hline Anglo American PLC & 57.6 & 47.6 & 49.7 & 48,6 & 48.0 \\
\hline Arch Resources Inc. & $(383.0)$ & 64.5 & 59.8 & 62.5 & 56.0 \\
\hline BHP Group PLC & 30.3 & 46.0 & 60.2 & 47.2 & 30.9 \\
\hline Coal India Ltd. & 56.6 & 37.0 & 26.9 & 33.8 & 42.0 \\
\hline JSW SA & $(170)$ & 2.3 & 36.1 & $(4.7)$ & $(4.0)$ \\
\hline LWB SA & 36.9 & 14.1 & $(2.0)$ & 4.8 & 49.6 \\
\hline Peabody Energy Corp. & - & 51.6 & 43.2 & 45.8 & 39.6 \\
\hline Raspadskaya PAO & 11.1 & $(45.5)$ & $(1.5)$ & 37.6 & 70.3 \\
\hline Rio Tinto PLC & 34.2 & 37.8 & 39.9 & 47.6 & 35.7 \\
\hline Vale SA Brazilian & 31.8 & 50.2 & 30.8 & 40.8 & 18.8 \\
\hline Whitehaven Coal Ltd. & 18.2 & 22.9 & 28.6 & $(6.7)$ & 20.1 \\
\hline
\end{tabular}

added that although positive levels of net working capital reduce this risk, to maintain them the company must refrain from actions that could bring it tangible benefits in the form of higher profitability (Fresand, 2012). For net working capital to be managed properly, it is imperative to determine its proper structure. It's may only be sourced from equity capital, only long-term external capital or a structure composed of both equity and long-term debt.

Neither too low nor too high a level of net working capital is beneficial for the company. A shortage of this capital leads to liquidity problems, and an excess may result in excess liquidity. In the latter case, the company has funds that it is not able to use effectively. (Nehrebecka, Białek- Jaworska, 2016). The reasons for this phenomenon can be both internal and external. Internal reasons are either related to errors made by managers or result from the liquidity management system in place. Systemic errors result from an overly conservative strategy of net working capital management, which makes excess liquidity a permanent phenomenon in the company. Another reason underlying errors in the management of net working capital in the company leading to temporary states of excess liquidity is non-implementation of mechanisms allowing for the harmonisation of the value of current assets and shortterm liabilities, the size and structure of which depend on factors related to the seasonality of operations. External reasons for the company's excess liquidity may be caused by one-off events e.g., related to the behaviour of business partners, or a relatively permanent change in the environment e.g., a reduction in market interest rates. However, the impact of external events on excess liquidity is not direct - the mere occurrence of any of the factors does not result in an excessive increase in free cash, provided that the company takes remedial measures. Therefore, external factors as stimuli of excess liquidity are tightly bound up with internal factors. The consequences for the company in the event of excess liquidity are limited to opportunity costs generated by unused funds. They often remain unnoticed either to external recipients of information or to company managers (Adamska 2016, Abbadi, 2013)). If excess liquidity persists, then it requires adjustments in the net working capital management strategy.

In practice, it is difficult to determine the optimum level of net working capital. It can only be said that companies enjoying ready access to short-term capital funding in the form of multi-purpose credit lines, factoring lines and large overdraft limits can afford to maintain low levels of net working capital. Net working capital may be boosted by increasing capital and long-term debt or releasing the capital tied up in the financing of fixed assets. Capital and long-term debt can be increased by limiting dividend pay-outs and increasing retained earnings, issuing shares and bonds, taking out additional long-term loans and borrowings, using financial leasing and other forms of long-term sources of funding. Fixed assets can be reduced by disposing of redundant fixed assets, selling buildings and leasing the necessary office space, leaseback of fixed assets, sale of financial instruments and limiting investments in this area (Sierpińska, Sierpińska-Sawicz, et al., 2019).

\section{Net Working Capital Strategies}

The choice of methods used in net working capital management depend on corporate strategy. The right strategy has a positive impact on the financial security of the company, its efficiency, competitiveness and financial performance (Andrew, Gallagher, 2007). G. Zimon (2016a) points out that errors in the management of net working capital are a common cause of bankruptcy. Therefore, company management is intent to look for solutions that ensure the company's liquidity and limit bankruptcy risk. In the management of net working capital, the solutions come down to rationalising the level of inventories and receivables and flexibly using short-term liabilities to finance the company's operating activities. A shortage of financing sources for these activities is supplemented with an appropriate level of net working capital. Systematic control of the level of net working capital reduces the costs of financing its acquisition.

Pertinent literature distinguishes three major strategies for managing net working capital: conservative, aggressive and moderate. By implementing a conservative strategy, the company's current assets exceed its short-term liabilities. It maintains a level of inventories which exceeds the industry average (Wędzki, 2003). Although inventories improve liquidity ratios, they also generate additional costs arising from their very maintenance. A prudent trade credit policy, manifesting itself through short invoice payment terms or demanding that new customers pay cash reduces overdue receivables (Sierpińska, 2020). It also leads to a lower than industry average level of receivables. Managers try to settle short-term liabilities in a timely manner; hence their level is relatively low. Current assets are largely financed through positive net working capital. A conservative working capital management strategy manifests itself in an extremely cautious approach to controlling current assets and sources of their financing. Managers refrain from measures that could threaten 
Tab. 2. Ratio of net working capital to total receivables and cash in mining companies, 2015-2019. Source: own calculations based on financial statements of mining companies retrieved from a Reuters database

Tab. 2. Relacja kapitału obrotowego netto do sumy należności i środków pieniężnych w spółkach górniczych w latach 2015-2019. Źródło: obliczenia własne na podstawie sprawozdań finansowych spółek górniczych zaczerpnięte z bazy Reuters

\begin{tabular}{|l|r|r|r|r|r|}
\hline Company & $\mathbf{2 0 1 5}$ & $\mathbf{2 0 1 6}$ & $\mathbf{2 0 1 7}$ & $\mathbf{2 0 1 8}$ & $\mathbf{2 0 1 9}$ \\
\hline Anglo American PLC & 96.1 & 78.6 & 79.2 & 83.4 & 87.9 \\
\hline Arch Resources Inc. & $(575.0)$ & 98.0 & 82.6 & 87.4 & 86.6 \\
\hline BHP Group PLC & 39.5 & 56.9 & 111.3 & 57.8 & 39.5 \\
\hline Coal India Ltd. & 79.7 & 58.8 & 46.9 & 61.1 & 81.6 \\
\hline JSW SA & $(313.2)$ & 3.0 & 43.3 & $(6.2)$ & $(7.4)$ \\
\hline LWB SA & 45.8 & 15.9 & $(2.3)$ & 6.1 & 59.3 \\
\hline Peabody Energy Corp. & $(1227.3)$ & 80.2 & 60.4 & 62.3 & 60.2 \\
\hline Raspadskaya PAO & 15.6 & $(63.6)$ & $(2.0)$ & 62.4 & 87.0 \\
\hline Rio Tinto PLC & 48.0 & 52.4 & 53.4 & 61.5 & 48.4 \\
\hline Vale SA Brazilian & 96.1 & 141.9 & 83.7 & 73.5 & 29.7 \\
\hline Whitehaven Coal Ltd. & 31.2 & 34.7 & 47.6 & 12.4 & 35.4 \\
\hline
\end{tabular}

the company's financial stability, in particular from incurring excessive liabilities to finance current assets.

An aggressive strategy involves keeping current assets and short-term liabilities at a similar level. The company does not use its net working capital to finance its operating activities. Inventories are kept below the industry average. As a result of an aggressive strategy of accounts receivable management, their level is higher than the industry average. The company applies long invoice payment terms and does not enforce strict security for receivables or limit trade credit availability for new contractors. Such a policy boosts sales and the acquisition of new markets. The extension of invoice payment terms though may result not only from the pursuit of an aggressive strategy, but also from the company's poor competitive edge or a need to liberalise its credit policy at a time when it is entering new markets or launching new products onto the market. An increase in total receivables is accompanied by an increase in overdue receivables and the costs of their collection. The increase in receivables is financed through an increase in short-term liabilities. However, if the increase in these liabilities is lower than the increase in receivables, the company should supplement its net working capital to reduce the liquidity risk.

In their business practice, companies try to follow a moderate strategy. They maintain a rational level of inventories to minimise related costs. Invoice payment terms map those granted by competitors. Companies try to reduce the risk of forfeiting their receivables by examining a buyer's financial standing and demanding security against their receivables. The moderate strategy is characterised by average balances of current assets and short-term liabilities. Consequently, both risk and profitability are moderate. "By deploying this type of strategy, the company tries to minimise the weaknesses of the conservative and aggressive strategies and maximise their advantages" (Zimoń, 2016b, p. 554). This means that a moderate working capital management strategy is a balancing act between aggressive and conservative approaches. With this method of working capital management, companies take greater risk when moulding the working capital structure than with the conservative strategy, but also one which is smaller than with an aggressive strategy. Individual working capital management strategies differ in terms of the scope of the spectrum of potential financial benefits and capital needs of the company (Szemraj, Czajkowska, 2020).

The correct determination of the working capital management strategy consists in developing an action plan that shows the possibilities of finding such financing that will satisfy the demand for working capital arising in the course of business activity, without running liquidity risk (Teofil-Kaczmarek, 2007). K. Kreczmańska-Gigol (2010) indicates that the primary goal of the strategy should be to optimise the capital structure of the company because other goals, such as minimising the risk of bankruptcy or maximising income are its resultants. The point of formulating a working capital management strategy arises from the need for long-term planning of activities aimed at (Szemraj, Czajkowska, 2020):

- raising funds to finance various areas of the company's activity,

- adjusting the level of assets to capital resources,

- maintaining the relationship between equity and external capital at a level that maximises the advantage of benefits over costs due to the capital structure,

- improving the coordination and monitoring of the way in which capital is spent,

- harmonisation of revenues and expenses.

\section{Research Methods}

The degree of financing of operating activities through net working capital was determined based on data taken from a Reuters database. Basic relationships based on net working capital were calculated.

1. Net working capital was calculated as the difference between current assets and accounts payable determined based on data from the balance sheets of the companies surveyed. The calculated share of net working capital in current assets shows the extent to which these assets are financed through long-term sources, which are more expensive than short-term sources, hence an excessive share of net working capital in the financing of current assets is not beneficial for companies as it increases the average cost of capital. This may limit the scope of profitable investment projects. Some investment projects may have a rate of return below the average cost of capital raised to finance them.

2. The share of net working capital in the financing of receivables and cash is expressed as a ratio of this capital to the sum of receivables and cash and cash equivalents. These are liquid components of current assets. When they is financed excessively through net working capital, this indicates a lack of rational capital management. 
Tab. 3. Ratio of short-term investments to net working capital 2015-2019. Source: own calculations based on financial statements of mining companies retrieved from a Reuters database

Tab. 3. Relacja inwestycji krótkoterminowych do kapitału obrotowego netto. Źródło: obliczenia własne na podstawie sprawozdań finansowych spółek górniczych zaczerpnięte z bazy Reuters

\begin{tabular}{|l|r|r|r|r|r|}
\hline Company & $\mathbf{2 0 1 5}$ & $\mathbf{2 0 1 6}$ & $\mathbf{2 0 1 7}$ & $\mathbf{2 0 1 8}$ & $\mathbf{2 0 1 9}$ \\
\hline Anglo American PLC & 86.9 & 101.0 & 107.5 & 101.4 & 95.0 \\
\hline Arch Resources Inc. & $(14.9)$ & 69.4 & 86.4 & 77.8 & 72.9 \\
\hline BHP Group PLC & 194.3 & 146.4 & 75.1 & 173.0 & 202.5 \\
\hline Coal India Ltd. & 97.4 & 121.9 & 177.9 & 139.4 & 81.4 \\
\hline JSW SA & $(13.8)$ & 2052.6 & 182.4 & - & - \\
\hline LWB SA & 110.6 & 441.0 & $(2918.8)$ & 752.9 & 103.8 \\
\hline Peabody Energy Corp. & $(4.3)$ & 80.8 & 107.1 & 109.5 & 114.6 \\
\hline Raspadskaya PAO & $154.8-$ & $(11.8)$ & $(500.0)$ & 20.4 & 73.6 \\
\hline Rio Tinto PLC & 181.6 & 149.9 & 155.7 & 139.4 & 172.2 \\
\hline Vale SA Brazilian & 72.9 & 37.6 & 74.0 & 92.7 & 255.6 \\
\hline Whitehaven Coal Ltd. & 195.4 & 190.4 & 100.7 & $(492.5)$ & 140.3 \\
\hline
\end{tabular}

3. The ratio of short-term investments (cash and cash equivalents) to net working capital is indicative of the extent to which long-term capital is involved in the financing of the most liquid current assets. When the value of this ratio exceeds 100 in the long term, this means that the company maintains temporary excess liquidity. A high level of financing of cash through long-term capital which persists over a long period of time may signal a low efficiency of capital use.

4. The ratio of net working capital to sales revenues indicates what level of net working capital is used to generate specific revenues. An increased burden placed on revenues in the form of net working capital requirement may deteriorate the profitability of sales.

\section{Assessment of the Engagement of Net Working Capital in the Financing of Current Assets in Mining Companies}

The share of net working capital in current assets in the surveyed companies presented in Table 1 indicates a relatively high involvement of long-term capital in the financing of operating activities. In the balance sheet, this is reflected in the level of inventories, receivables, short-term investments and short-term deferred charges and accruals.

At an average of $60 \%$ in 2016-2019, Arch Resources reported the highest level of financing of current assets through net working capital. At Anglo American and the BHP Group, the ratio reached $50 \%$. In several companies, it amounted to $30 \%$. Notably, in Polish coal companies it was very low. In the last two years of the period analysed, JSW SA reported negative net working capital indicating that accounts payable were used to finance part of the fixed assets. In Polish coal companies, the share of net working capital in current assets was highly volatile. In LWB, in 2017 negative net working capital accounted for $2.0 \%$ of current assets, and in 2019 almost 50\% of these assets were financed through long-term capital. Similarly, in the Russian company Raspadskaya, 2017 saw a negative working capital, and in 2019 this capital financed $70 \%$ of current assets. The degree of current asset financing through long-term capital depends to a large extent on the level of maintained inventories of extracted raw materials. If a company extracts multiple raw materials, such as copper, iron ore, coal, molybdenum, cobalt, etc., and has distant sales markets, it must maintain a high level of inventories to ensure regular deliveries to customers. Companies such as Anglo American, BHP Group, Rio Tinto, and Vale SA have diverse activities.
They have a more stable share of net working capital in the financing of current assets than companies mining only coal.

Table 2 shows the share of net working capital involved in the financing of receivables and cash and their equivalents. A high degree of this involvement may indicate an irrational use of long-term capital. Long-term capital is more expensive than the short-term one. It includes equity capital, the raising of which does not reduce the tax base. Dividends paid to shareholders are a direct cost arising from equity. Long-term external capital generates higher costs than short-term capital due to a higher risk premium, continuity of availability and security pledged. For example, long-term loans are secured by a mortgage or lien on movable property, while short-term loans are secured by an assignment of receivables or a bank or insurance guarantee.

The analysed coal companies reveal a high level of financing of liquid current assets through net working capital. It averages $60-80 \%$ and results from the level of free cash kept in accounts, as indicated by the data in Table 3. In Polish coal companies, the degree of liquid assets financing through net working capital is low and varies over time. Yet, the above does not validate the conclusion that net working capital is too low to finance receivables and short-term investments. To determine if correct sources of financing of operating activities were selected, attention should be paid to the structure of liquid assets and the share of cash in them. When a high share of cash in relation to net working capital persists in the long run, it is not good for the company.

By engaging long-term capital that makes up the net working capital, the company incurs the costs of its acquisition. Free cash however, even if invested in the short term, generates a much lower rate of return than the cost of raising capital. Therefore, the company incurs opportunity costs, i.e., the costs of frozen capital not invested in more profitable assets.

In general, companies should not use excess net working capital to finance operating activities if they hold surplus cash. They should maintain an optimum level of cash, which is a compromise between minimising the risk of insolvency and maximising the profit from long-term investments in their development. At Anglo-American, the level of cash and cash equivalents held is equal to net working capital. In 2019, cash at BHP was more than twice as high as its net working capital. In Polish mining companies, the levels of this ratio in selected years were exceptionally high. At the end of 2016, JSW SA held PLN 1,170 million in its account and its working capital 
Tab. 4. Ratio of net working capital to sales revenues in mining companies, 2015-2019. Source: own calculations based on financial statements of mining companies retrieved from a Reuters database

Tab. 4. Relacja kapitału obrotowego netto do przychodów ze sprzedaży w spółkach górniczych w latach 2015-2019. Źródło: obliczenia własne na podstawie sprawozdań finansowych spółek górniczych zaczerpnięte z bazy Reuters

\begin{tabular}{|l|r|r|r|r|r|}
\hline Company & $\mathbf{2 0 1 5}$ & $\mathbf{2 0 1 6}$ & $\mathbf{2 0 1 7}$ & $\mathbf{2 0 1 8}$ & $\mathbf{2 0 1 9}$ \\
\hline Anglo American PLC & 0.39 & 0.28 & 0.27 & 0.23 & 0.22 \\
\hline Arch Resources Inc. & $(1.69)$ & 0.29 & 0.21 & 0.22 & 0.17 \\
\hline BHP Group PLC & 0.19 & 0.27 & 0.49 & 0.25 & 0.16 \\
\hline Coal India Ltd. & 0.49 & 0.31 & 0.21 & 0.24 & 0.36 \\
\hline JSW SA & $(0.37)$ & 0.01 & 0.16 & $(0.02)$ & $(0.02)$ \\
\hline LWB SA & 0.13 & 0.07 & $(0.08)$ & 0.01 & 0.17 \\
\hline Peabody Energy Corp. & $(1.07)$ & 0.23 & 0.17 & 0.17 & 0.14 \\
\hline Raspadskaya PAO & 0.07 & $(0.59)$ & $(0.01)$ & 0.30 & 0.78 \\
\hline Rio Tinto PLC & 0.15 & 0.17 & 0.19 & 0.24 & 0.14 \\
\hline Vale SA Brazilian & 0.25 & 0.39 & 0.18 & 0.18 & 0.09 \\
\hline Whitehaven Coal Ltd. & 0.07 & 0.05 & 0.05 & $(0.01)$ & 0.03 \\
\hline
\end{tabular}

totalled a mere PLN 57 million. In 2018, cash amounted to PLN 1,651 million and negative working capital to PLN 164 million. The company did not finance its most liquid assets i.e., cash and cash equivalents through long-term capital. In 2018, LWB SA held PLN 171 million in its account and its working capital totalled a mere PLN 22.7 million, so cash was 7.5 times higher than its working capital. This indicates rational capital management under which even a small amount of cash held relative to a low level of working capital would indicate excess liquidity, hence the presented ratios must be viewed with caution. Only long-term cash balances significantly exceeding working capital may be indicative of excess liquidity. Such excess liquidity is visible in the ratio of cash to net working capital in BHP Group, Rio Tinto and Whitehaven Coal. It results from large fluctuations in the bottom line.

Assessment of the adequacy of net working capital management must not disregard the relation of this capital to sales revenues (Table 4 ). The ratio is highly volatile because of changes in specific net working capital management strategies. In the conditions of stiff competition, companies extend invoice payment terms inflating the level of receivables. Likewise, increasing the availability of products requires that the level of inventories be increased, which, in turn, necessitates the use of more capital and long-term debt to finance current assets. The lowest level of net working capital involvement in relation to revenues is reported by Polish coal companies. They do not maintain excessive stocks of coal. At JSW SA, the inventory cycle is 30 days, and at LWB SA it totals 20 days. In large corporations pursuing diverse activities, 1 PLN of revenue corresponds on average to PLN 0.20 net working capital. In coal companies, this ratio is more stable than in coal companies. The use of net working capital to finance sales revenues is influenced by changes in the demand for coal and its prices.

\section{Conclusions}

Summing up, it should be emphasised that net working capital in the company serves to reduce the risk resulting from lower liquidity of some current assets (inventories, receivables) or from maturity dates of accounts payable. Net working capital is a financial cushion at the company's disposal at all times and can be used as a source of financing of operating activities. By using net working capital, the company bears the cost of capital. Hence, the involvement of this capital in operating activities must be balanced, on the one hand in terms of costs, and on the other, in terms of the company's debt servicing capacity. Too high a share of net working capital in the financing structure of current assets depresses the profitability of companies' activity. Meanwhile, a high share of net working capital in the financing of current assets is often the reason for a positive assessment of the company, especially by external stakeholders, who use it to weigh the risk of the company's insolvency. In mining companies, a high share of net working capital in the financing of current assets results from the need to maintain inventories of mined raw materials. Polish mining companies use net working capital to finance current assets to a much lesser extent than global companies. This confirms the hypothesis proposed in the research. In many global companies, a high ratio of net working capital to cash indicates excess liquidity. This signals to managers that they should change their strategy of net working capital management. 


\section{Literatura - References}

1. Abbadi R.T., Abbadi S.M. (2013). The determinants of working capital requirements in Palestinian industrial corporations, International Journal of Economics and Finance, 5(1), pp. 65-75.

2. Adamska A. (2016) Ryzyko płynności finansowej przedsiębiorstwa i jego raportowanie. https://www.researchgate. net/publication/322738386 (retrieved 9.03.2021).

3. Andrew J. Gallagher T. (2007) Financial Management, Principles and Practice. Freeload Press, Madison Wisconsin.

4. Comporek M. (2017). Kapitał obrotowy netto jako determinanta operacyjnego bezpieczeństwa finansowego przedsiębiorstwa, Prace Naukowe Uniwersytetu Ekonomicznego we Wrocławiu, no 484, pp.59-74.

5. Ching H.Y., Novazzi A., Gerab F., Relationship between working capital management and profitability in Brazilian listed companies, "Journal of Global Business and Economics" 2011, vol. 3, no 1, pp.74-86.

6. Fresard L. (2012), Cash savings and stock price informativeness, Review of Finance, 16(4), pp. 985-1012.

7. Nehrebecka N Białek-Jaworska A. (2016). Determinanty oszczędności i nadpłynności przedsiębiorstw w Polsce, Bank i Kredyt, 47(2), pp.153-194.

8. Sierpińska M. (2020). Coal Companies’ Trade Credit Policy, Inżynieria Mineralna, no 1, pp. 231-236.

9. Sierpińska M., Sierpińska-Sawicz A., Węgrzyn R. (2019). Controlling finansowy w przedsiębiorstwie, WN PWN Warszawa.

10. Sierpinska M., Jachna T. (2007). Metody podejmowania decyzji finansowych. Analiza przykładów i przypadków, WN PWN Warszawa.

11. Skoczylas W. (2015). Pomiar dokonań w zarzadzaniu kapitałem obrotowym netto. Zeszyty Naukowe Uniwersytetu Szczecińskiego, nr 873, Finanse, rynki finansowe, Ubezpieczenia, no 77, pp.411-421.

12. Szemraj T., Czajkowska A. (2020). Taktyki i strategie zarządzania kapitałem obrotowym w finansowaniu przedsiębiorstw, Wydawnictwo Uniwersytetu Łódzkiego, Łódź 2020.

13. Zimoń G. (2016a). Kapitał obrotowy a ryzyko utraty płynności finansowej. Zeszyty Naukowe Uniwersytetu Szczecińskiego, Finanse. Rynki Finansowe. Ubezpieczenia, nr 4 (82), part1, pp.311-320.

14. Zimoń G. (2016b). Koszty zarzadzania kapitałem obrotowym w przedsiębiorstwach handlowych. Prace Naukowe Uniwersytetu Ekonomicznego we Wrocławiu, no 442, pp. 552-560.

Rola kapitału obrotowego netto w finansowaniu działalności operacyjnej spółek górniczych $W$ artykule podjęto problem wykorzystania kapitału obrotowego netto do finansowania operacyjnej działalności przedsiębiorstw. Kapitał obrotowy netto to długoterminowe źródła finansowania (kapitał własny i obce kapitały długoterminowe) droższe od źródeł krótkoterminowych, stąd racjonalne ich wykorzystanie ma istotny wpływ na efektywność funkcjonowania przedsiębiorstwa. Ustalony poziom kapitału obrotowego netto jest podstawą konstrukcji wskaźników umożliwiających sterowanie tym kapitałem. Wskaźniki te to relacje kapitału obrotowego netto do aktywów obrotowych, do sumy należności i inwestycji krótkoterminowych, do środków pieniężnych $i$ ich ekwiwalentów oraz przychodów ze sprzedaży. W oparciu o tak obliczone relacje dokonano oceny zaangażowania kapitału obrotowego netto do finansowania operacyjnej działalności spótek górniczych. Spółki te utrzymuja wysoki stopień finansowania aktywów obrotowych kapitałami długoterminowymi. W spółkach górniczych o zdywersyfikowanej działalności wydobywczej poziom finansowania aktywów obrotowych kapitałem długoterminowym jest wyższy niż w spółkach wydobywajacych węgiel. Jest to wynikiem utrzymywania wyższego poziomu zapasów wydobywanych surowców, odległości rynków zbytu od miejsca wydobycia oraz rodzaju wykorzystywanego transportu. Na podstawie relacji kapitału obrotowego netto do środków pieniężnych i ich ekwiwalentów ustalono, że w niektórych spółkach występuje nadpłynność finansowa. Środki pieniężne sa znacznie wyższe niż ten kapitał w okresie trzech - czterech lat. Nadwyżka środków pieniężnych nad kapitałem obrotowym netto w krótkim okresie nie może być traktowana jako nadplynność finansowa, gdyż jest wynikiem elastycznego zarzadzania tym kapitałem.

Słowa kluczowe: kapitał obrotowy netto, relacje oparte na kapitale obrotowym netto, nadplynność finansowa 